\title{
Anodic fabrication and bioactivity of Nb-doped $\mathrm{TiO}_{2}$ nanotubes
}

\author{
Dongyan Ding ${ }^{1}$, Congqin Ning ${ }^{2,4}$, Lin Huang ${ }^{1,2}$, Fangchun Jin ${ }^{3}$, \\ Yongqiang $\mathrm{Hao}^{3}$, Shuo Bai ${ }^{1}$, Yan $\mathrm{Li}^{1}$, Ming $\mathrm{Li}^{1}$ and Dali Mao \\ ${ }^{1}$ Lab of Microelectronic Materials and Technology, State Key Laboratory of Metal Matrix \\ Composites, School of Materials Science and Engineering, Shanghai Jiao Tong University, \\ Shanghai 200240, People's Republic of China \\ ${ }^{2}$ Biomaterials and Tissue Engineering Research Center, Shanghai Institute of Ceramics, \\ Chinese Academy of Sciences, Shanghai 200050, People's Republic of China \\ ${ }^{3}$ Ninth People's Hospital, Shanghai Jiao Tong University School of Medicine, \\ Shanghai 200011, People's Republic of China
}

E-mail: cqning@mail.sic.ac.cn

Received 23 February 2009, in final form 27 April 2009

Published 7 July 2009

Online at stacks.iop.org/Nano/20/305103

\begin{abstract}
We report anodic formation of $\mathrm{Ti}-\mathrm{Nb}-\mathrm{O}$ nanotubes on top of a Ti35 $\mathrm{Nb}$ alloy, and in vitro bioactivity and stem cell response of the anodic nanotubes. It was found that the amorphous $\mathrm{Ti}-\mathrm{Nb}-\mathrm{O}$ nanotubes presented a significantly enhanced in vitro bioactivity (in simulated body fluids) compared to those of undoped $\mathrm{TiO}_{2}$ nanotubes and porous $\mathrm{Ti}-\mathrm{Nb}-\mathrm{O}$ without nanotubular structure. Similar to undoped $\mathrm{TiO}_{2}$ nanotubes, the $\mathrm{Ti}-\mathrm{Nb}-\mathrm{O}$ nanotubes also promote mesenchymal stem cell adhesion and fast formation of extracellular matrix (ECM) materials. The above findings make it possible to further explore the biological properties, such as cell proliferation and drug delivery, of a variety of Ti-alloy-based oxide nanotubes.
\end{abstract}

(Some figures in this article are in colour only in the electronic version)

\section{Introduction}

Biomedical Ti and its alloys have been widely used as implant materials, mainly due to their excellent biocompatibility, corrosion resistance and moderate mechanical properties $[1,2]$. $\mathrm{Ti}$ and its alloys cannot bond chemically to the surrounding bone, which would result in bone resorption around the implant and eventual failure of the implantation [3]. To form a chemical bond, surface modification is needed. Among various surface modification methods, including plasma coating and etching [4], anodization of the Ti metal or alloys to form a bioactive transition layer may be a simple but efficient way to achieve chemical bonding.

As $\mathrm{TiO}_{2}$ nanotubes have shown excellent physical and chemical properties that are favorable for many applications including photocatalysis and gas sensing as well as biomedical applications. Many works have been reported on the anodization of pure $\mathrm{Ti}$ to form amorphous $\mathrm{TiO}_{2}$ nanotubes and further crystallized nanotubes after heat-treatment [5-7].

\footnotetext{
4 Author to whom any correspondence should be addressed.
}

$\mathrm{TiO}_{2}$ nanotubes have shown a good bioactivity in simulated body fluids and cell culture [8-12]. $\mathrm{TiO}_{2}$ nanotubes loaded with different drugs, like antibiotics or alendronate, have exhibited sustained drug release [13, 14]. Based on this progress, anodization of $\mathrm{Ti}$ alloys to fabricate doped $\mathrm{TiO}_{2}$ nanotubes (for tunable nanostructures and properties) has aroused great interest in recent years. Macak et al investigated the anodization of Ti6Al7Nb and Ti6Al4V alloys [15]. Ghicov et al reported the anodization of Ti45 Nb alloy to grow Ti$\mathrm{Nb}-\mathrm{O}$ nanotubes, which show enhanced thermal stability in comparison with that of titania nanotubes [16]. Feng et al also fabricated self-organized nanotube coatings on a Ti28Zr8Nb alloy [17]. Considering the great advantages (better corrosion resistance, higher wear resistance and enhanced tissue response) of low-modulus $\beta$-type alloys for clinical applications $[1,18]$, oxide nanotubes grown on low elastic modulus alloys are expected to have a bright future.

To date, however, the biological properties (including in vitro bioactivity and cell response) of $\mathrm{Ti}-\mathrm{Nb}-\mathrm{O}$ nanotubes, and many other Ti-alloy-based anodic nanotubes, have not been reported. In the present work, Ti35Nb alloy was anodized 
to fabricate $\mathrm{Ti}-\mathrm{Nb}-\mathrm{O}$ nanotubes on top of a $\mathrm{Ti} 35 \mathrm{Nb}$ alloy surface. In vitro bioactivity and mesenchymal stem cell (MSC) adhesion behaviors of the $\mathrm{Ti}-\mathrm{Nb}-\mathrm{O}$ nanotubes were investigated.

\section{Experimental details}

As-cast Ti35Nb alloy ( $\beta$-type Ti alloy with an elastic modulus of $68 \mathrm{GPa}$ ) plates with a size of $10 \mathrm{~mm} \times 10 \mathrm{~mm} \times 1 \mathrm{~mm}$ were ground and polished with $2000 \#$ SiC emery papers, and then ultrasonically cleaned with absolute alcohol. Finally they were rinsed with deionized water and dried in a $\mathrm{N}_{2}$ stream. Electrochemical anodization was conducted with a DC voltage stabilizer. All of the samples were anodized at 10-20 V for $1.5 \mathrm{~h}$ in an $1 \mathrm{M}\left(\mathrm{NH}_{4}\right)_{2} \mathrm{SO}_{4}$ solution containing $0.5 \mathrm{wt} \% \mathrm{NH}_{4} \mathrm{~F}$. After anodization, the samples were rinsed with deionized water and dried in a $\mathrm{N}_{2}$ stream. For comparison, pure Ti plates were also anodized at $15 \mathrm{~V}$ to obtain undoped $\mathrm{TiO}_{2}$ nanotubes with an inner diameter of about $60 \mathrm{~nm}$ and a length of about $950 \mathrm{~nm}$.

Some of the samples anodized at $15 \mathrm{~V}$ were immersed in simulated body fluid (SBF) to evaluate the in vitro bioactivity $[19,20]$. The $\mathrm{SBF}$ was prepared by dissolving reagent-grade $\mathrm{NaCl}, \mathrm{NaHCO}_{3}, \mathrm{KCl}, \mathrm{K}_{2} \mathrm{HPO}_{4} \cdot 3 \mathrm{H}_{2} \mathrm{O}$, $\mathrm{MgCl}_{2} \cdot 6 \mathrm{H}_{2} \mathrm{O}, \mathrm{CaCl}_{2}$ and $\mathrm{Na}_{2} \mathrm{SO}_{4}$ in deionized water. The fluid was then buffered to $\mathrm{pH} 7.4$ at $37^{\circ} \mathrm{C}$ with tris(hydroxymethyl) aminomethane $\left[\mathrm{NH}_{2} \mathrm{C}\left(\mathrm{CH}_{2} \mathrm{OH}\right)_{3}\right]$ and hydrochloric acid $(\mathrm{HCl})$. During the in vitro testing process, the $\mathrm{SBF}$ was refreshed every day. After immersion in the SBF for different times, the samples were taken out of the SBF, rinsed with deionized water and finally dried in air for further surface examination.

Mouse bone marrow MSCs (mMSC) [21, 22] were cultured and passaged. Cells from the fourth passage were used in the present work. Some of the samples anodized at $15 \mathrm{~V}$ were autoclaved and then put in a 24 -well plate. One milliliter of cell suspension with a cell density of $2 \times 10^{5}$ cells ml $\mathrm{m}^{-1}$ was added to each well. After different culture times (2, 6, 12 and $24 \mathrm{~h}$ ), the cultured samples were rinsed with phosphatebuffered saline (PBS) solution to remove non-adherent cells. The stem cells were fixed with $2.5 \%$ glutaraldehyde solution. Samples were then rinsed with PBS solution, dehydrated in a series of ethanol $(30 \%, 50 \%, 70 \%, 80 \%, 90 \%, 95 \%, 100 \%)$ for 20 min each and finally dried with hexamethyldisilizane.

The cell cultured samples were then sputter-coated with a thin conducting layer of gold (10 $\mathrm{nm}$ in thickness) to facilitate further surface observation. Surfaces of the above as-anodized, SBF-treated and cell cultured samples were characterized with scanning electron microscope (SEM; FEI SIRION 200) and energy dispersive $\mathrm{X}$-ray analysis (EDXA; OXFORD INCA). The operating voltage for the SEM observation was $5 \mathrm{kV}$. Phase structures of the as-anodized samples as well as the alloy substrate were investigated with x-ray diffraction (XRD; $\mathrm{D} / \mathrm{max} 2550 \mathrm{~V})$.

\section{Results and discussion}

Figure 1 presents an optical microscope image of $\beta$-matrix grains of the $\mathrm{Ti} 35 \mathrm{Nb}$ alloy, which was polished and etched

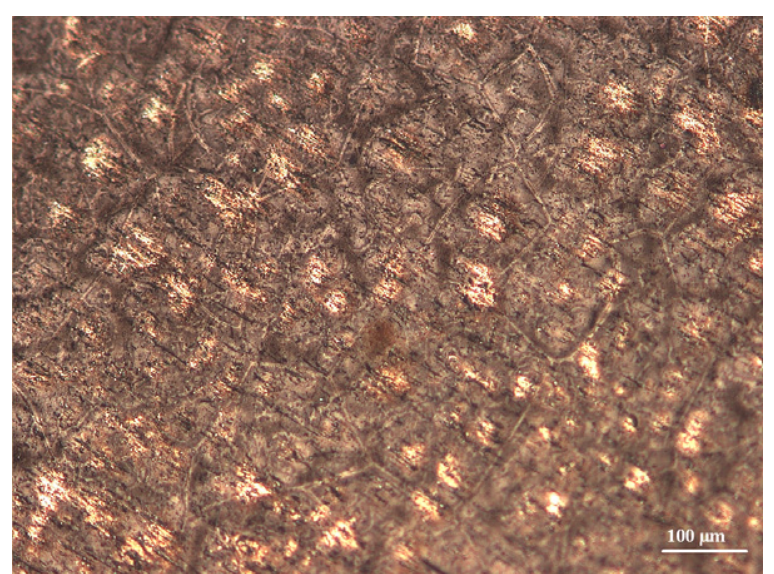

Figure 1. Optical microscope image showing the $\beta$-matrix grains of the $\mathrm{Ti}-35 \mathrm{Nb}$ alloy. Nearly straight grain boundaries can be seen.

according to standard metallographic procedures. The average diameter of the $\beta$-matrix grains is around $150 \mu \mathrm{m}$. Figure 2 shows surface morphologies of the Ti35Nb alloy sample anodized at different voltages. It could be found that, at a lower anodization voltage of $10 \mathrm{~V}$, only porous structures rather than nanotubular structures could form on the sample surface (figure 2(a)). Such a low-voltage anodization process corresponded to an initial anodization stage [23], during which nanotubes could not form. With increase of the anodization voltage to 15 and $20 \mathrm{~V}$, aligned nanotubular structures ( $\mathrm{Ti}-\mathrm{Nb}-$ O nanotubes) could grow at the sample surfaces (figures 2(b) and (c)).

To reveal the cross-sectional morphology of the above $\mathrm{Ti}-\mathrm{Nb}-\mathrm{O}$ nanostructures, surfaces of the as-anodized samples were deliberately scratched to obtain partially fractured nanotubes (figure 3). From our SEM observations, it could be found that both the average diameter and the length of the nanopores or nanotubes increased with an increase in the anodization voltage. At $10 \mathrm{~V}$ the average inner diameter of the nanopores is less than $20 \mathrm{~nm}$ and the length of the nanoporous structure is within several hundred of nanometers. At $15 \mathrm{~V}$, the average inner diameter of the $\mathrm{Ti}-\mathrm{Nb}-\mathrm{O}$ nanotubes is about $60 \mathrm{~nm}$ (with a nanotube wall thickness of about $5 \mathrm{~nm}$ ) and the average length of the nanotubes is $1.2 \mu \mathrm{m}$ (figure 3(a)). The EDXA pattern of the Ti-Nb-O nanotubes fabricated at $15 \mathrm{~V}$ reveals that the weight percentage of the $\mathrm{Nb}$ and $\mathrm{O}$ elements in the nanotubes is about $28.1 \%$ and $34.1 \%$, respectively. Xray diffraction of the as-anodized samples indicates that all of the oxide nanostructures are amorphous. As the anodic coating could form a tight and conformal bonding to the alloy substrate and high-temperature heat-treatment may cause damage to the mechanical properties of nanotube-coated alloy implants, we directly use the amorphous nanostructures for the following biological evaluations.

To evaluate the in vitro bioactivity, three kinds of nanostructures, i.e. the $\mathrm{Ti}-\mathrm{Nb}-\mathrm{O}$ nanotubes fabricated at $15 \mathrm{~V}$, the undoped $\mathrm{TiO}_{2}$ nanotubes fabricated at $15 \mathrm{~V}$ and the porous $\mathrm{Ti}-\mathrm{Nb}-\mathrm{O}$ fabricated at $10 \mathrm{~V}$, were investigated. Figure 4 presents surface morphologies of the $\mathrm{Ti}-\mathrm{Nb}-\mathrm{O}$ nanotube samples immersed in SBF for various times. After immersion 

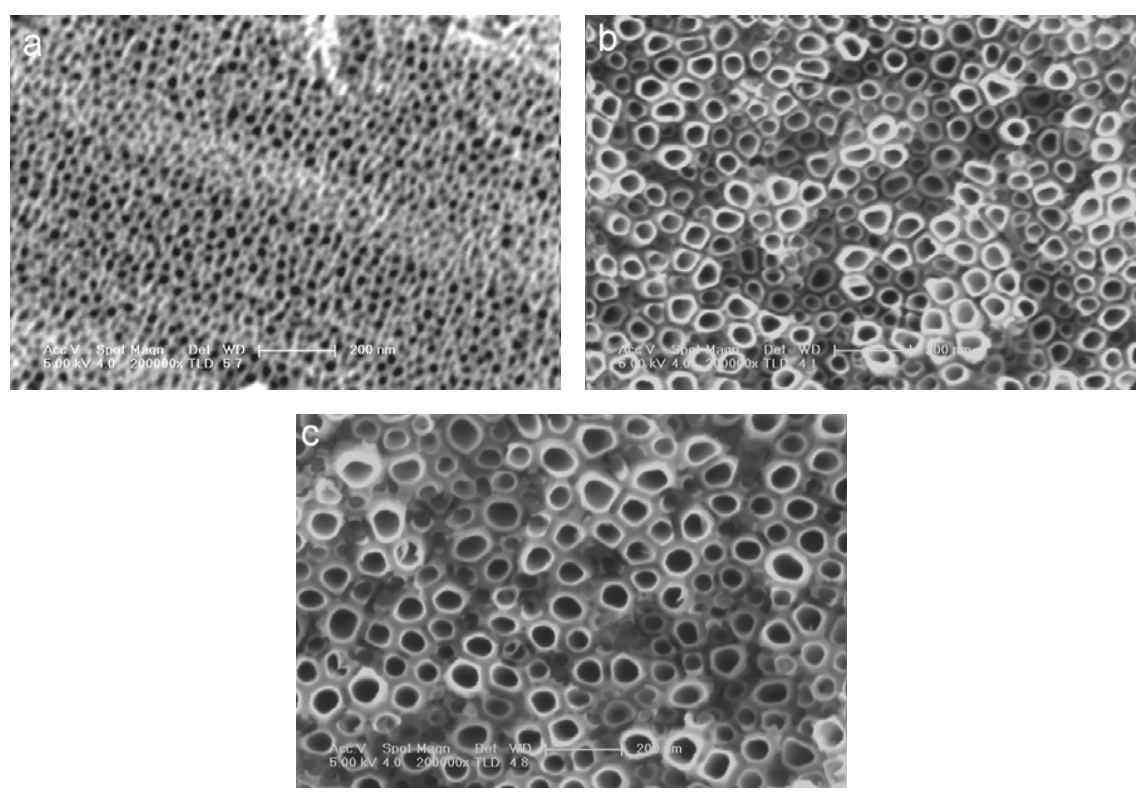

Figure 2. Ti-Nb-O nanostructures grown at different anodization voltages: (a) Porous $\mathrm{Ti}-\mathrm{Nb}-\mathrm{O}$ without nanotubular structures fabricated at $10 \mathrm{~V}$, (b) $\mathrm{Ti}-\mathrm{Nb}-\mathrm{O}$ nanotubes fabricated at $15 \mathrm{~V}$ and (c) $\mathrm{Ti}-\mathrm{Nb}-\mathrm{O}$ nanotubes fabricated at $20 \mathrm{~V}$.
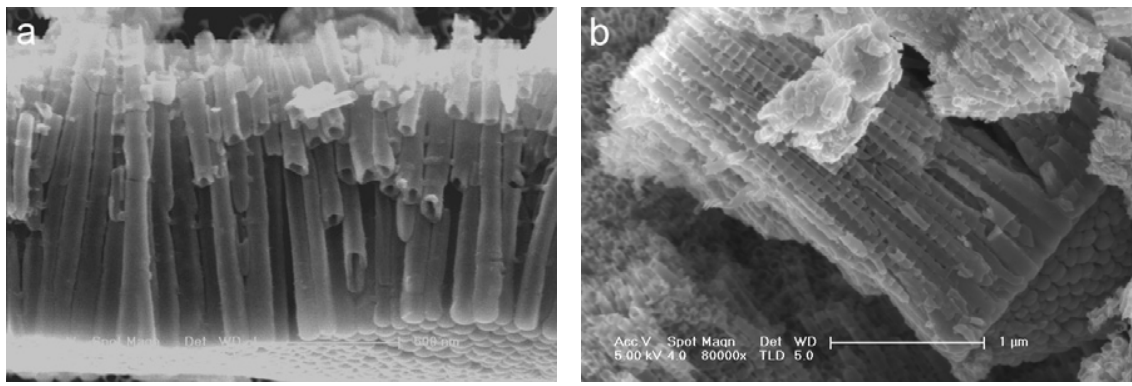

Figure 3. Cross-sectional image of Ti-Nb-O nanotubes grown at an anodization voltage of (a) $15 \mathrm{~V}$ and (b) $20 \mathrm{~V}$. Surfaces of the as-anodized samples were deliberately scratched to obtain partially fractured nanotubes, which are randomly distributed and present no alignment.
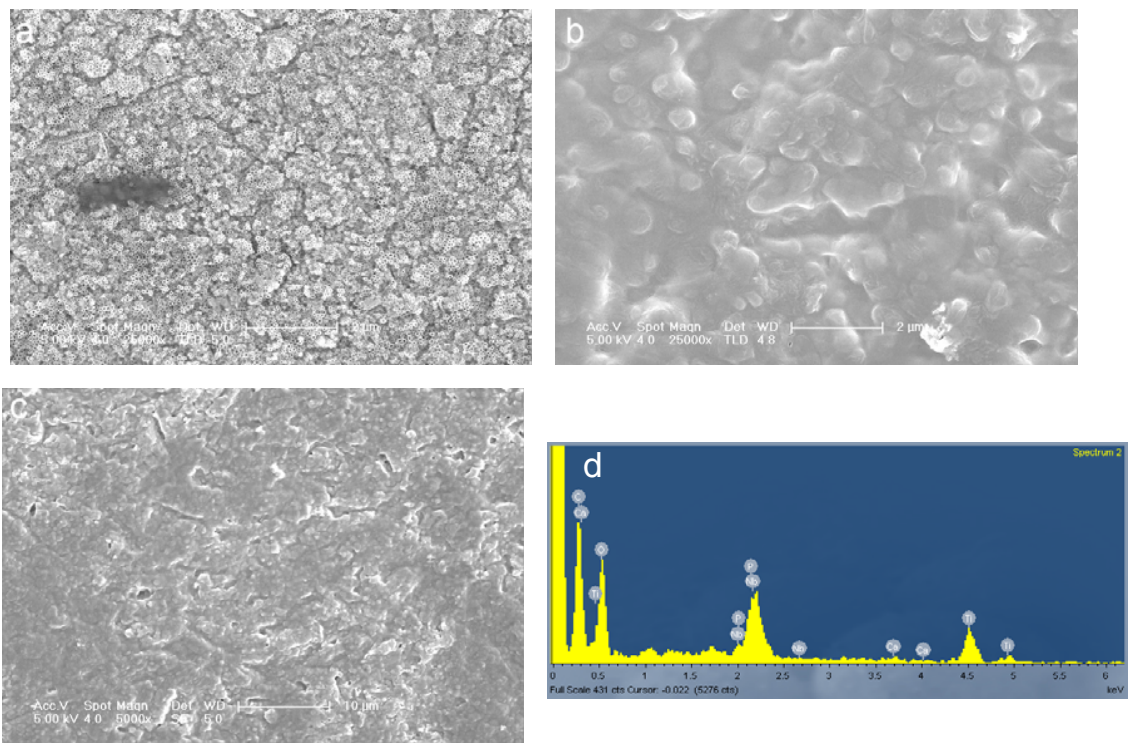

Figure 4. Surface morphologies of the Ti-Nb-O nanotube sample immersed in SBF for (a) 1 day and (b) and (c) 7 days. The EDXA pattern of the surface deposition (formed after immersion for 7 days) is shown in (d). 


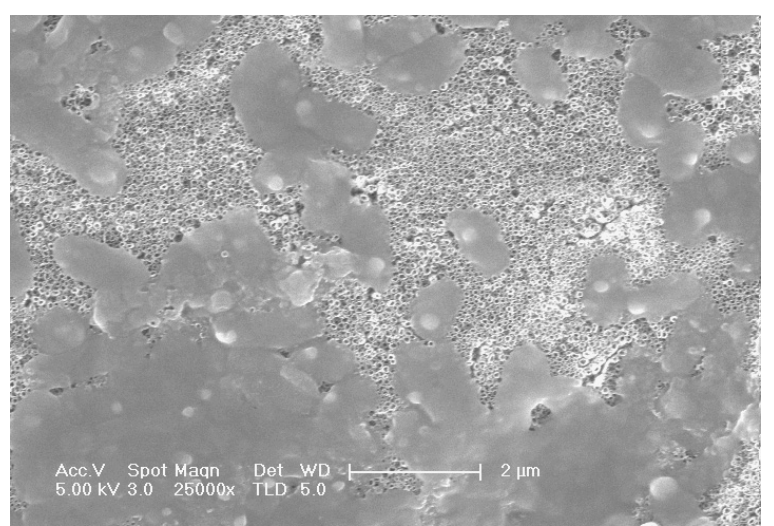

Figure 5. Surface morphology of the undoped $\mathrm{TiO}_{2}$ nanotube sample immersed in SBF for 7 days.

for 1 day, apatite formation could be clearly found on the surface of the $\mathrm{Ti}-\mathrm{Nb}-\mathrm{O}$ nanotubes and most of the top ends of the nanotubes had not been covered with the apatite (figure 4(a)). After immersion for 7 days the nanotubes were totally covered with deposited apatite (figures 4(b) and (c)). Similar to the apatite formation on Ti-Al-V-O nanostructures [24], the EDXA pattern in figure 4(d) indicated that the deposition is a kind of carbonated apatite that contains $\mathrm{Ca}, \mathrm{P}$ and $\mathrm{O}$ elements (three main elements of apatite-like or apatite depositions) as well as a considerable amount of elemental C.

For comparison, in vitro bioactivity of the undoped $\mathrm{TiO}_{2}$ nanotubes and the porous $\mathrm{Ti}-\mathrm{Nb}-\mathrm{O}$ without nanotubular structures was also investigated. Figures 5 and 6 present surface morphologies of the pure $\mathrm{TiO}_{2}$ nanotube sample and the porous $\mathrm{Ti}-\mathrm{Nb}-\mathrm{O}$ sample immersed in the $\mathrm{SBF}$ for 7 days. As can be seen from figure 5, a large area of $\mathrm{TiO}_{2}$ nanotubes could not be covered with deposited apatite even after immersion of the samples in the SBF for 7 days. For the porous $\mathrm{Ti}-\mathrm{Nb}-\mathrm{O}$ sample, only a thin layer of apatite formed on the surface (figure 6). Obviously, Ti-Nb-O nanotubes present a higher in vitro bioactivity than the porous $\mathrm{Ti}-\mathrm{Nb}-\mathrm{O}$ without nanotubular structures, and much higher in vitro bioactivity than the undoped $\mathrm{TiO}_{2}$ nanotubes.

Figure 7 shows the attachment of MSCs on the Ti-Nb-O nanotubes (fabricated at an anodization voltage of $15 \mathrm{~V}$ ) after different culture times. With regard to cell response, the Ti$\mathrm{Nb}-\mathrm{O}$ nanotubes presented good bioactivity for the adhesion and spreading of mouse bone marrow MSCs. As can be seen in figures 7(a) and (b), after a $2 \mathrm{~h}$ cell culture, a large quantity of high-density stem cells could attach and spread on the nanotube surfaces. With increase of the cell culture time to 6 , 12 and $24 \mathrm{~h}$, the number of attached (and/or spread) stem cells increased. In figure 7(c), it can be found that the cell adhesion was so evident that most of the stem cells presented a flat shape, which covered much more area than those for the short-time cultured samples. After $24 \mathrm{~h}$ of cell culture, the spreading or protrusion of the stem cells was so strong that nearly all of the surface areas were covered with stem cells, which show flat shapes and numerous filopodia (figure 7(d)). Obviously, the $\mathrm{Ti}-\mathrm{Nb}-\mathrm{O}$ nanotubes could allow quick cell adhesion and spreading on the nanotubular surfaces.

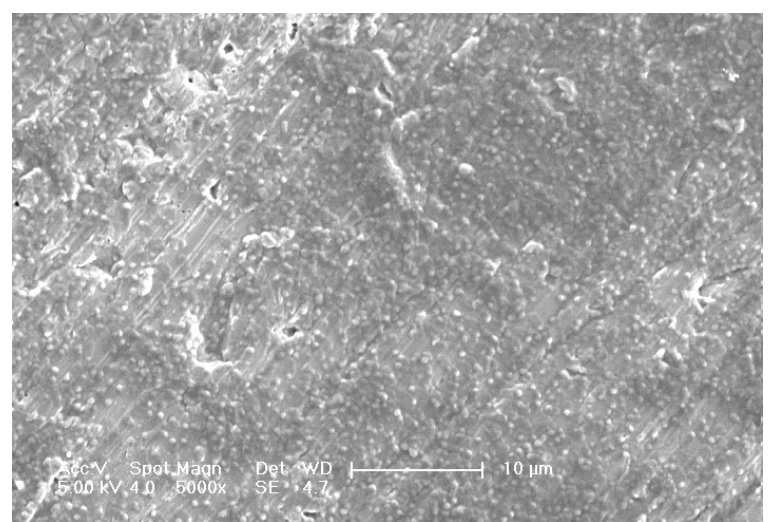

Figure 6. Surface morphology of the porous $\mathrm{Ti}-\mathrm{Nb}-\mathrm{O}$ sample immersed in SBF for 7 days.

Figure 8 shows the attachment of MSCs on the undoped $\mathrm{TiO}_{2}$ nanotubes after different culture times. It can be found that the undoped $\mathrm{TiO}_{2}$ nanotubes also presented moderate adhesion and spreading of a number of stem cells on the nanotubular surfaces after $2 \mathrm{~h}$ of cell culture (figures 8(a) and (b)) and strengthened cell activity upon further cell culture (figure 8(c)). Compared to the $\mathrm{MSC} \mathrm{TiO}{ }_{2}$ nanotube system, there was not much difference in the above mentioned short-time cell response to the $\mathrm{Ti}-\mathrm{Nb}-\mathrm{O}$ nanotubes, i.e. the cell adhesion rate of the $\mathrm{Ti}-\mathrm{Nb}-\mathrm{O}$ nanotubes seems to be comparable to that of the undoped $\mathrm{TiO}_{2}$ nanotubes (exact comparison of the cell adhesion rate for different surfaces may be available after a detailed MTT assay analysis of both the doped and undoped nanotubes). Considering that many factors (such as nanotube diameter and length as well as spacing) could affect the bioactivity (such as vitality, proliferation, differentiation, etc) of cells like MSCs and osteoblasts [10], more experimental work is still needed to find the exact mechanisms of cell interaction with the $\mathrm{Ti}-\mathrm{Nb}-\mathrm{O}$ nanotubes. We are now conducting the corresponding investigations.

In addition, a close examination of both the $\mathrm{Ti}-\mathrm{Nb}-$ $\mathrm{O}$ nanotube and $\mathrm{TiO}_{2}$ nanotube areas reveals that after a short culture time of only $2 \mathrm{~h}$ the nanotubular surfaces no longer existed, i.e. all of the cell-free nanotube areas were totally covered with extracellular matrix (ECM) type materials. According to Brammer and Li et al [12, 25, 26], ECM could serve as a substrate for subsequent cell adhesion and migration, and the status of the ECM (such as composition, density and distribution) plays an important role in the interaction of cells with nanomaterials. Compared to the reported $\mathrm{MSC} / \mathrm{TiO}_{2}$ nanotube system cultured for 1 day [25], the speed of ECM formation in the present MSC/Ti-Nb-O and $\mathrm{MSC} / \mathrm{TiO}_{2}$ nanotube system is much quicker. Such rapid ECM formation is expected to facilitate cell response, including fast cell signaling and abundant nutrient reserves.

As reported by Popat and Hilder et al [13, 14, 27], nanotubular structures like undoped $\mathrm{TiO}_{2}$ nanotubes could demonstrate remarkable drug delivery properties due to their large adsorption areas and one-dimensional substance transportation. We believe that the highly bioactive $\mathrm{Ti}-\mathrm{Nb}-$ $\mathrm{O}\left(\mathrm{Nb}\right.$-doped $\mathrm{TiO}_{2}$ ) nanotubes could also serve as a sound 

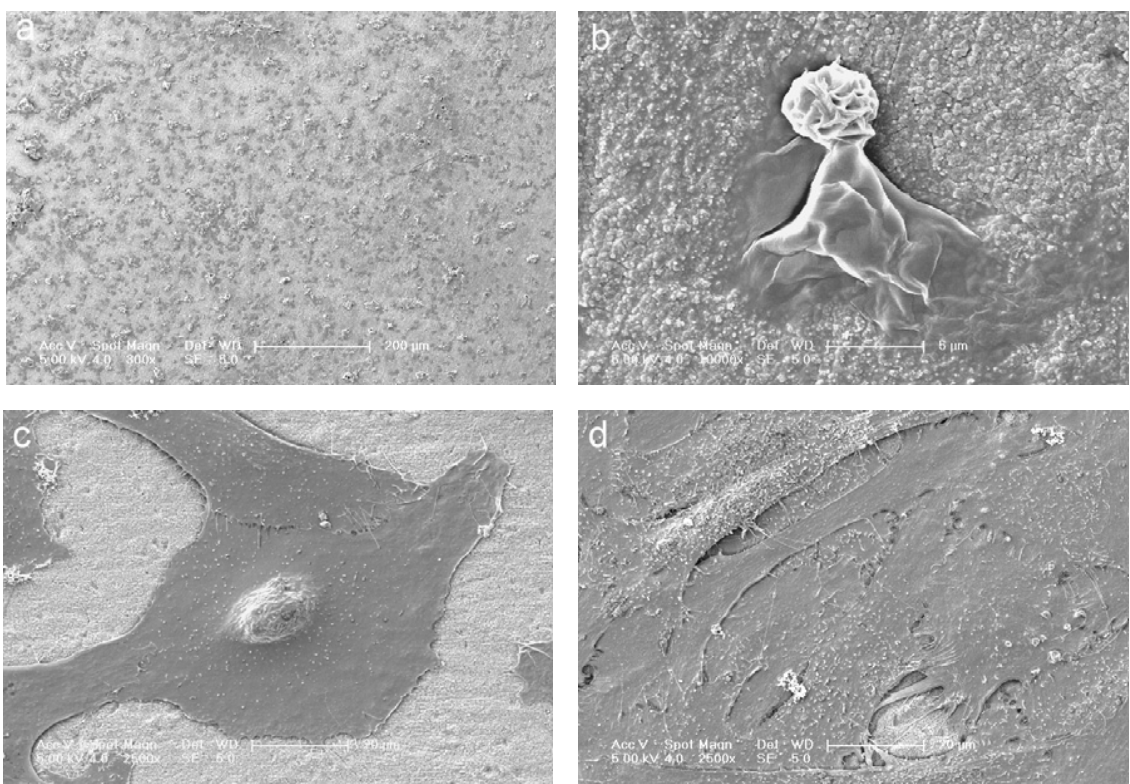

Figure 7. Attachment of stem cells on the Ti-Nb-O nanotubes after a culture time of (a), (b) $2 \mathrm{~h}$, (c) $12 \mathrm{~h}$ and (d) $24 \mathrm{~h}$.
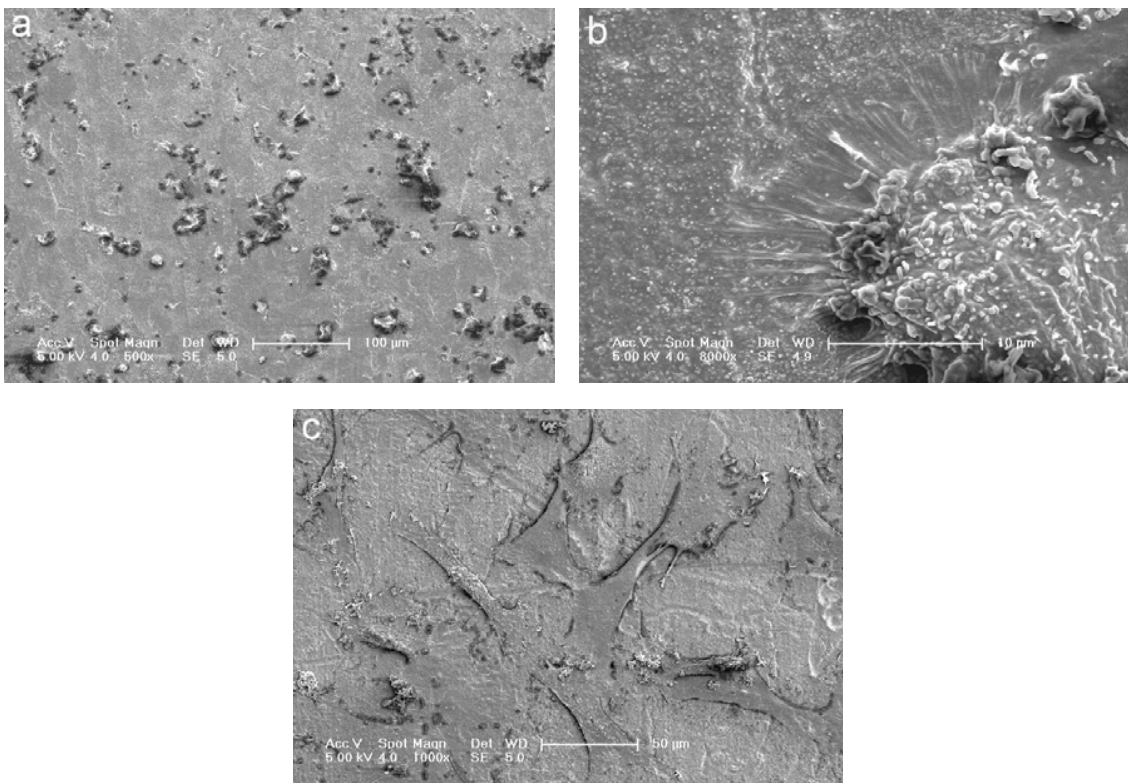

Figure 8. Attachment of stem cells on the undoped $\mathrm{TiO}_{2}$ nanotubes after a culture time of (a), (b) $2 \mathrm{~h}$ and (c) $24 \mathrm{~h}$.

drug delivery platform for orthopedic and dental applications. Further works are needed to verify such an expectation for functionalized $\mathrm{Ti}-\mathrm{Nb}-\mathrm{O}$ nanotubes. Regarding mechanical considerations, the adhesion force between the Ti-Nb-O nanotubes (of different sizes) and the substrate should be also investigated and controlled through proper anodization or size optimization, to avoid weak bonding between the implant devices and environment.

\section{Conclusions}

In summary, anodic $\mathrm{Ti}-\mathrm{Nb}-\mathrm{O}$ nanotubes present a significantly enhanced in vitro bioactivity in comparison with undoped
$\mathrm{TiO}_{2}$ nanotubes and porous $\mathrm{Ti}-\mathrm{Nb}-\mathrm{O}$ without nanotubular structures. The Ti-Nb-O nanotubes also present a good bioactivity for mesenchymal stem cell adhesion and spreading as well as extracellular matrix formation. This nanotube/alloy system has great potential for biomedical applications especially in orthopedic and dental implants.

\section{Acknowledgments}

This work was supported by Shanghai Pujiang Program (no. 07pj14047) and 863 Plan of China (no. 2006AA02A1). We acknowledge the contribution from the SEM lab at the Instrumental Analysis Center of SJTU. 


\section{References}

[1] Long M J and Rack H J 1998 Biomaterials 19 1621-39

[2] Zhu X L, Chen J, Scheideler L, Reichl R and Geis-Gerstorfer J 2004 Biomaterials 25 4087-103

[3] Qing L, Jiang D, Francis K M, Stephanie L W and George R B 2002 Biomaterials 23 3103-11

[4] Chu P K, Chen J Y, Wang L P and Huang N 2002 Mater. Sci. Eng. R 36 143-206

[5] Gong D W, Grimes C A, Varghese O K, Hu W, Singh R S, Chen Z and Dickey E C 2001 J. Mater. Res. 16 3331-4

[6] Varghese O K, Gong D W, Paulose M, Grimes C A and Dickey E C 2003 J. Mater. Res. 18 156-65

[7] Macak J M, Tsuchiya H and Schmuki P 2005 Angew. Chem. Int. Edn 44 2100-2

[8] Tsuchiya H, Macak J M, Müller L, Kunze J, Müller F, Greil P, Virtanen S and Schmuki P 2006 J. Biomed. Mater. Res. A 77 534-41

[9] Oh S, Daraio C, Chen L, Pisanic T R, Finones R R and Jin S 2006 J. Biomed. Mater. Res. A 78 97-103

[10] Park J, Bauer S, von der Mark K and Schmuki P 2007 Nano Lett. 7 1686-91

[11] Bauer S, Park J, von der Mark K and Schmuki P 2008 Acta Biomater. 4 1576-82

[12] Brammer K S, Oh S, Gallagher J O and Jin S 2007 Nano Lett. 8 786-93

[13] Popat K C, Eltgroth M, LaTempa T J, Grimes C A and Desai T A 2007 Small 3 1878-81
[14] Popat K C, Eltgroth M, LaTempa T J, Grimes C A and Desai T A 2007 Biomaterials 28 4880-8

[15] Macak J M, Tsuchiya H, Taveira L, Ghicov A and Schmuki P 2005 J. Biomed. Mater. Res. A 75 928-33

[16] Ghicov A, Aldabergenova S, Tsuchiya H and Schmuki P 2006 Angew. Chem. Int. Edn $2006456993-6$

[17] Feng X, Macak J M, Albu S P and Schmuki P 2008 Acta Biomater. 4 318-23

[18] Puelo D A and Nancy A 1999 Biomaterials 20 2311-21

[19] Ohtsuki C, Kokubo T and Yamamuro T 1992 J. Non-Cryst. Solids 143 84-92

[20] Ning C Q and Zhou Y 2002 Biomaterials 23 2909-15

[21] Pittenger M F, Mackay A M, Beck S C, Jaiswal R K, Douglas R, Mosca J D, Moorman M A, Simonetti D W, Craig S and Marshak D R 1999 Science 284 143-7

[22] Zhou Y F, Bosch-Marce M, Okuyama H, Krishnamachary B, Kimura H, Zhang L, Huso D L and Semenza G L 2006 Cancer Res. 66 10849-54

[23] Taveira L V, Macak J M, Tsuchiya H, Dick L F P and Schmuki P 2005 J. Electrochem. Soc. 152 B405-10

[24] Li Y, Ding D, Ning C, Bai S, Huang L, Li M and Mao D 2009 Nanotechnology 20065708

[25] Popat K, Leoni L, Grimes C and Desai T 2007 Biomaterials 28 3188-97

[26] Li S, Bhatia S, Hu Y L, Shiu Y T, Li Y S, Usami S and Chien S 2001 Biorheology 38 101-8

[27] Hilder T A and Hill J M 2009 Small 5 300-8 